\title{
Analisa RII (Relative Important Index) Terhadap Faktor-Faktor yang Berpengaruh dalam Mengimplementasikan BIM 4D dan M-PERT pada Pekerjaan Struktur Bangunan Hunian Bertingkat Tinggi
}

\author{
Frisky Sustiawan ${ }^{1, *}$, Albert Eddy Husin ${ }^{2}$ \\ Magister Teknik Sipil, Universitas Mercu Buana, Jakarta \\ Koresponden*, Email: friskysustiawan91@gmail.com
}

\begin{tabular}{|c|c|c|}
\hline & Info Artikel & Abstract \\
\hline Diajukan & 09 Juni 2021 & This study discusses the factors influencing BIM 4D and M-PERT implementation on high- \\
\hline Diperbaiki & 15 Agustus 2021 & rise residential building structures using RII (Important Relative Index) analysis. The \\
\hline Disetujui & 15 Agustus 2021 & $\begin{array}{l}\text { research was conducted using a quantitative descriptive method by distributing ques- } \\
\text { tionnaires to practitioners related to the work of high-rise residential structures. The study } \\
\text { found that ten factors had the most influence on implementing BIM } 4 \text { D and M-PERT on } \\
\text { high-rise residential structures, namely other detailed drawings, project schedule, percentage }\end{array}$ \\
\hline $\begin{array}{l}\text { Keywords: } \\
\text { Construtiol }\end{array}$ & $\begin{array}{l}\text { RT, BIM 4D, Schedule, } \\
\text { ect }\end{array}$ & $\begin{array}{l}\text { of delays. , activity modeling, project activity integration, network similarity, building design } \\
\text { planning, scheduling integration, visualization, increase productivity }\end{array}$ \\
\hline
\end{tabular}

\begin{abstract}
Penelitian ini membahas mengenai faktor - faktor yang berpengaruh dalam mengimplementasikan BIM 4D dan M-PERT pada pekerjaan struktur bangunan hunian tingkat tinggi dengan menggunakan Analisa RII (Relative Important Index). Penelitian dilakukan dengan metode deskriptif kuantitatif dengan menyebar kuisoner ke praktisi yang berkaitan dengan pekerjaan struktur hunian bertingkat tinggi, hasil penelitian didapatkan bahwa ada 10 faktor paling berpengaruh terhadap implementasi BIM 4D dan M-PERT pada pekerjaan struktur hunian bertingkat tinggi, yaitu antara lain detail gambar, schedule proyek, presentase keterlambatan, pemodelan aktivitas, penggabungan kegiatan proyek, kemiripan jaringan, perencanaan desain bangunan, integrasi penjadwalan, visualisasi, dan meningkatkan produktivitas
\end{abstract}

\section{Pendahuluan}

Tren Hunian bertingkat tinggi sekarang ini semakin tumbuh pesat, hal ini dipicu dengan semakin banyaknya kebutuhan orang terhadap tempat tinggal namun tidak didukung oleh ketersediaan lahan. Meningkatnya tren ini dapat dilihat pada Gambar 1 dan Gambar 2. Bangunan apartemen vertikal saat ini menjadi pilihan yang paling tepat. Hal tersebut dikarenakan menipisnya luas lahan yang tersedia, sehingga efisiensi lahan diperlukan. Harga tanah yang selangit, membangun hunian vertikal akan lebih murah dan lebih menguntungkan karena unit yang bisa dibangun lebih banyak, dengan luas lahan yang terbatas.

Dalam proyek konstruksi, faktor utama bagi kontraktor adalah biaya, waktu, dan mutu.Ketiga faktor tersebut saling berhubungan satu dengan yang lain. Biaya, waktu, dan mutu merupakan faktor yang harus dikendalikan dalam proyek konstruksi. Pengendalian yang tidak tepat dapat mengakibatkan kegagalan suatu proyek. Pengendalian harus dilakukan dari mulai awal proyek sampai dengan selesainya suatu proyek. Pada proyek konstruksi pengendalian waktu berupa jadwal yang disusun sebelum mulai pekerjaan, penyusunan jadwal dapat dilakukan memakai beberapa metode misalnya metode Gantt Chart, Network Planning Diagram, Curve-S dll.

Secara perencanaan penjadwalan ada beberapa metode, misalnya metode CPM, PDM, PERT, dan M-PERT. Metode CPM ialah metode jalur kritis (Critical Path Method), yakni metode untuk merencanakan dan mengawasi proyek-proyek. CPM merupakan sistem yang paling banyak dipergunakan diantara semua sistem lain yang memakai prinsip pembentukan jaringan. CPM pada dasarnya menitikberatkan pada persoalan keseimbangan antara biaya dan waktu penyelesaian proyek-proyek yang besar. Dengan CPM, jumlah waktu yang diperlukan untuk menyelesaikan berbagai taraf dari pada proyek dianggap diketahui dengan pasti; lebihlebih hubungan antara jumlah sumber-sumber yang digunakan dan waktu yang diperlukan untuk menyelesaikan proyek juga dianggap diketahui. Sehingga, CPM juga dapat didefinisikan sebagai suatu analisa jaringan kerja yang berusaha mengoptimalkan biaya total proyek melalui pengurangan atau percepatan waktu penyelesaian total proyek yang bersangkutan [1].

Keterlambatan pada proyek dapat terjadi karena beberapa faktor. Faktor - faktor tersebut dapat dilihat pada Tabel 1 
Tabel 1. Faktor Keterlambatan Proyek [2]

\begin{tabular}{lllll}
\hline Number & \multicolumn{1}{c}{ 15 Most important factors causing delays } & Factor grup & RII & Rank \\
\hline 1 & Inadequate contractor experience & Contractor related & 0,863 & 1 \\
2 & Ineffective project planning and scheduling & Contractor related & 0,844 & 2 \\
3 & Poor site management and supervision & Contractor related & 0,844 & 2 \\
4 & Design changes by owner or agent during construction & Design related & 0,813 & 4 \\
5 & Late delivery of materials & Material related & 0,803 & 5 \\
6 & Unreliable subcontractors & Contractor related & 0,797 & 6 \\
7 & Delay in performing inspection and testing & Consultant related & 0,784 & 7 \\
8 & Unqualified/inexperienced workers & Labor related & 0,784 & 7 \\
9 & Change orders & Owner related & 0,778 & 9 \\
10 & Delay in site delivery & Owner related & 0,778 & 9 \\
11 & Delay in approving design documents & Owner related & 0,775 & 11 \\
12 & Delay in progress payments & Owner related & 0,775 & 11 \\
13 & Slowness in decision making & Owner related & 0,775 & 11 \\
14 & Poor communication and coordination with other parties & Consultant related & 0,756 & 14 \\
15 & Unexpected surface and subsurface conditions (soil, $h w$ t.) & External related & 0,780 & 14 \\
\hline
\end{tabular}

\section{Cumulative Supply}

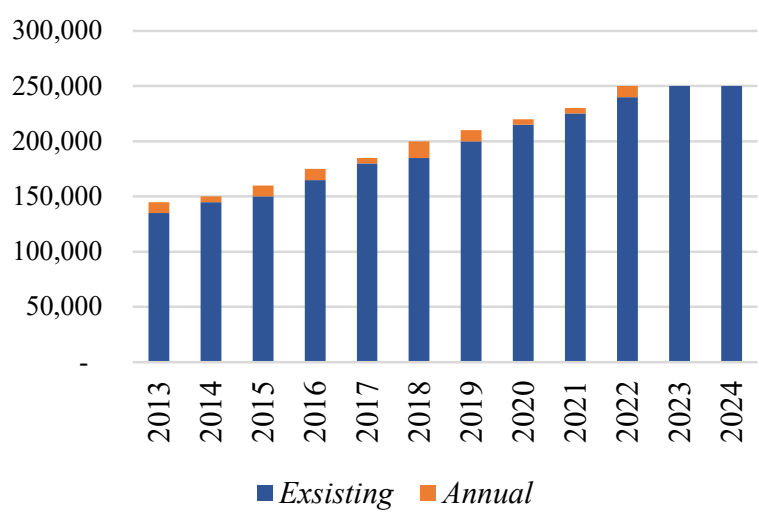

Gambar 1. Data Supply bertingkat tinggi di Jakarta [3]

Faktor keterlambatan proyek pada Tabel 1 hanya diambil 15 faktor yang paling berpengaruh terhadap keterlambatan proyek. Di urutan pertama adalah pengalaman kontraktor yang tidak mencukupi. Di urutan kedua adalah perencanaan penjadwalan yang tidak tepat. Penjadwalan yang kurang tepat dapat membuat proyek berjalan tidak beraturan dan tidak sesuai dengan perencanaan, hal ini dapat menyebabkan proyek terlambat, akibatnya secara biaya dan mutu juga bisa tidak tercapai sesuai dengan rencana [2].

Dari beberapa faktor - faktor tersebut menjadi menarik untuk di teliti dimana penulis akan membahas lebih detail mengenai perbaikan kinerja struktur bangunan hunian tingkat tinggi pada bagian pengendalian waktu di proyek konstruksi dengan menggunakan BIM 4D dan M-PERT.

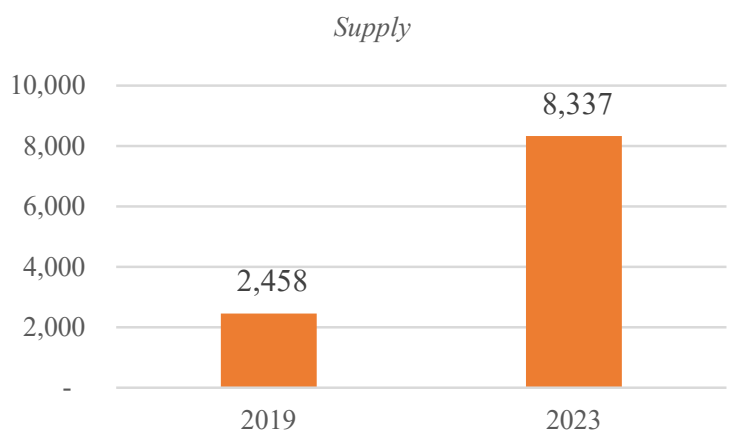

Gambar 2. Data Supply Hunian bertingkat tinggi [3]

\section{Metode}

Metode penelitian adalah pada dasarnya merupakan cara ilmiah untuk mendapatkan data yang valid dengan tujuan yang bersifat penemuan, pembuktian dan pengembangan suatu pengetahuan sehingga hasilnya dapat digunakan untuk memahami, memecahkan dan mengantisipasi masalah [4].

Penelitian ini merupakan penelitian deskriptif kuantitatif. Metode deskriptif adalah metode yang digunakan untuk menganalisis data dengan cara mendeskripsikan atau menggambarkan data yang telah terkumpul sebagaimana adanya tanpa bermaksud membuat kesimpulan yang berlaku untuk umum atau generalisasi [4]. Sedangkan penelitian kuantitatif adalah metode penelitian berlandaskan pada filsafat positivism, digunakan untuk meneliti pada populasi atau sampel tertentu, teknik pengambilan sampel pada umumnya dilakukan secara random, pengumpulan data menggunakan instrumen penelitian, analisis data bersifat kuantitatif atau statistik dengan tujuan untuk menguji hipotesis yang telah ditetapkan [4]. 


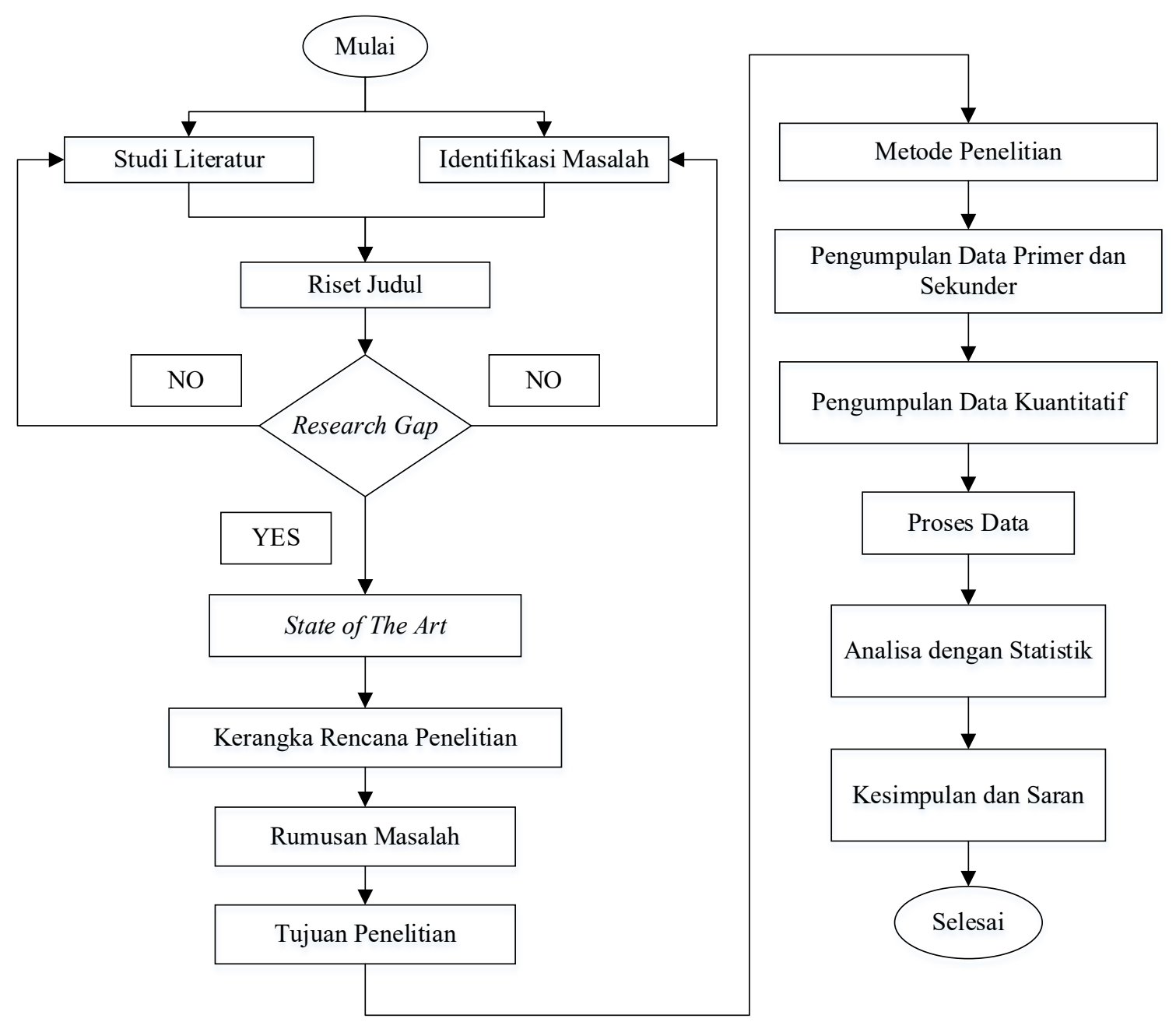

Gambar 3. Diagram alir penelitian

Strategi penelitian yang digunakan untuk melakukan penelitian ini adalah strategi survei. Metode survei adalah metode yang digunakan untuk mendapatkan data dari tempat tertentu yang alamiah (bukan buatan), tetapi peneliti melakukan perlakuan dalam pengumpulan data, misalnya dengan mengedarkan kuisioner, test, wawancara terstruktur dan sebagainya [4].

Proses penelitian dapat dilihat pada Gambar 3. dalam pengerjaan penelitian ini peneliti mengikut kaedah yang telah di buat berupa alur kerja, sehingga tidak terjadi penyimpangan dalam proses penelitian nya. Research novelty penelitian ini dapat dilihat pada Tabel 2, dimana pada Tabel 2 menunjukkan posisi penelitian ada pada metode BIM 4D dan M-PERT dengan jenis bangunan hunian bertingkat tinggi dan lingkup pekerjaannya struktur.

Penelitian ini menggunakan metode survei, dimana data yang diperoleh dilakukan analisis dan penyusunan model matematika yang menunjukkan hubungan antara identifikasi penyebab ketidakefisiensian waktu dalam proses produksi dengan pengaruh aplikasi BIM 4D dan M-PERT pada proyek struktur hunian gedung bertingkat tinggi terhadap waktu. Hubungan tersebut dapat digambarkan dalam bentuk grafik $\mathrm{Y}=\mathrm{f}(\mathrm{X})$, di mana struktur Hunian gedung bertingkat tinggi digambarkan sebagai sumbu Y, sedangkan penerapan penjadwalan metode BIM 4D dan M-PERT sebagai variabel bebas digambarkan pada sumbu $\mathrm{X}$, sebagaimana ditunjukkan pada Gambar 4

Relative Importance Index (RII) merupakan metode dalam menganalisis faktor-faktor yang paling berpengaruh dalam objek penelitian. Selain itu juga metode analisis ini diolah dengan perhitungan statistik dengan hasil kuesioner sebagai input yang nantinya akan diproses menjadi faktor berpengaruh. RII menentukan faktor yang paling berpengaruh dengan sistem ranking berdasarkan bobot dari nilai yang diberikan dari responden setelah mengisi kuesioner. Pada penelitian terdahulu penggunaan metode RII dipakai untuk menentukan 
faktor berpengaruh dalam penelitian, melalui perhitungan dengan persamaan 1 :

$\mathrm{RII}=\Sigma \mathrm{W} /(\mathrm{A} \times \mathrm{N})$

dimana:
$\mathrm{RII}=$ Relative Importance Index

$\mathrm{W}=$ Weight $($ Bobot dengan range 1 sampai dengan 5)

$\mathrm{A}=$ bobot tertinggi

$\mathrm{N}=$ total responden

Tabel 2. Research Novelty [2]

\begin{tabular}{lccccccc}
\hline \multirow{2}{*}{$\begin{array}{c}\text { Metode } \\
\text { Waktu }\end{array}$} & \multirow{5}{*}{ Stadium } & Perumahan & $\begin{array}{c}\text { Jndustri dan } \\
\text { Perkantoran }\end{array}$ & $\begin{array}{c}\text { Hunian } \\
\text { Bertingkat Tinggi }\end{array}$ & Struktur & Arsitektur & MEP \\
\hline PERT & {$[5]$} & {$[6]$} & {$[7]$} & {$[8]$} & {$[8]$} & {$[8]$} & {$[8]$} \\
CPM & {$[5]$} & {$[9]$} & {$[8]$} & {$[10]$} & {$[9],[5]$} & {$[9],[5]$} & {$[5]$} \\
M-PERT & & & {$[11],[12]$} & & {$[12]$} & {$[13]$} & \\
BIM 4D & {$[14]$} & {$[15]$} & {$[16]$} & {$[17]$} & {$[18],[17]$} & {$[17]$} & {$[19]$} \\
\hline
\end{tabular}

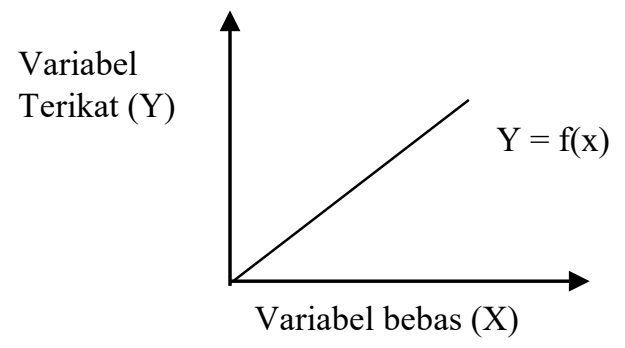

Gambar 4. Grafik variabel

Nilai RII memiliki bentang antara 0 sampai dengan 1 (nilai 0 tidak termasuk). Skor tertinggi RII akan menjadi faktor paling berpengaruh dalam penelitian. RII kemudian dibuat ranking untuk masing-masing sub factor. Perhitungan nilai rata-rata RII dijadikan sebagai nilai RII untuk masingmasing main faktor yang terkandung sub factor. Hasilnya berupa peringkat dari sub factor, main factor, dan variabel [2]. Analisis statistik menggunakan metode Relative Importance Index (RII) memiliki beberapa langkah dan pengujian sampai hasil faktor berpengaruh yang diperoleh valid dan reliabel, uji validitas dan realibilitas menjadi faktor penentu keputusan.

Kuesioner disusun berdasarkan kajian kepustakaan dan relevansi dengan tujuan penelitian. Wawancara dengan expert yang sudah memiliki banyak pengalaman akan membantu meningkatkan kekuatan kuesioner untuk mendapatkan hasil penelitian yang tepat [13].

Hipotesis penelitian terdapat dua bentuk hipotesis yaitu hipotesis nol $\left(\mathrm{H}_{0}\right)$ dan hipotesis yang berlawanannya $\left(\mathrm{H}_{1}\right)$. $\mathrm{H}_{0}$ merupakan pernyataan tidak adanya hubungan, pengaruh, atau perbedaan antara parameter statsitik. Sedangkan $\mathrm{H}_{1}$ merupakan lawan dari $\mathrm{H}_{0}$ yang menyatakan adanya hubungan, pengaruh, atau perbedaan antara parameter statistik. $\mathrm{H}_{0}$ disusun dalam kalimat negative [20]. Berikut ini merupakan hipotesis $\mathrm{H}_{1}$ dan $\mathrm{H}_{0}$ pada penelitian analisa $\mathrm{RII}$ terhadap faktor - faktor yang berpengaruh dalam mengimplementasikan BIM 4D dan M-PERT pada pekerjaan struktur bangunan hunian bertingkat tinggi:

a. $\mathrm{H}_{1}=$ terdapat hubungan BIM 4D dan M-PERT terhadap pelaksanaan schedule pekerjaan struktur hunian gedung bertingkat tinggi.

b. $\mathrm{H}_{0}=$ tidak terdapat hubungan BIM 4D dan M-PERT terhadap pelaksanaan schedule pekerjaan struktur hunian gedung bertingkat tinggi.

Penentuan jumlah sampel selalu berpusat seberapa banyak sampel atau seberapa minimum sampel diambil dari suatu populasi. Ada pedoman statistika dalam menentukan jumlah sampel, yaitu semakin banyak jumlah sampel diambil semakin jelas gambaran keadaan populasi dipaparkan [21].

Jumlah responden minimum untuk menjawab kuesioner diperlukan sebagai batasan dalam pengumpulan hasil yang dibutuhkan. Kebutuhan responden dapat diperoleh dengan menggunakan persamaan 2 dan persamaan 3 [22]:

$m=\frac{Z^{2} \times P \times(1-P)}{\varepsilon^{2}}$
$n=\frac{m}{1+\left(\frac{m-1}{N}\right)}$

Dimana:

$\mathrm{n}=$ jumlah responden minimum

$\mathrm{Z}=$ Confidence level

$\mathrm{P}=$ nilai proporsi populasi

Setelah didapat hasil kuesioner yang sudah direkapitulasi pada tahap sebelumnya, maka dilakukan 3 (tiga) pengujian data responden yaitu uji validitas, reliabilitas dan uji hipotesis. Uji tersebut dilakukan supaya hasil yang diperoleh berkualitas berdasarkan dengan kriteria teknik pengujian. Berikut ini merupakan uji yang harus dilakukan: 


\section{Uji Validitas}

Uji Validitas adalah suatu ukuran yang menunjukkan tingkat keandalan atau kesahihan suatu alat ukur. Alat ukur yang kurang valid berarti memiliki validitas yang rendah [20]. Untuk menguji validitas alat ukur terlebih dahulu dicari nilai korelasi antara bagian-bagian dari alat ukur secara keseluruhan dengan cara mengorelasikan setiap butir alat ukur dengan skor total yang merupakan jumlah dari masingmasing skor butir dengan rumus Pearson Product Moment pada persamaan 4:

$$
r \text { hitung }=\frac{n \cdot \Sigma(X Y)-\left(\sum X\right) \cdot\left(\sum Y\right)}{\sqrt{\left(n \cdot \Sigma X^{2}-\left(\sum X\right)^{2}\right) \cdot\left(n \cdot \Sigma Y^{2}-\left(\sum Y\right)^{2}\right)}}
$$

dimana:

$$
\begin{array}{ll}
\mathrm{r}_{\text {hitung }} & =\text { koefisien korelasi } \\
\Sigma \mathrm{X} & =\text { jumlah skor item } \\
\Sigma \mathrm{Y} & =\text { jumlah skor Total } \\
\Sigma \mathrm{XY} & =\text { jumlah (skor item } \mathrm{x} \text { skor total) } \\
\Sigma \mathrm{X} 2 & =\text { skor item kuadrat lalu dijumlahkan } \\
\Sigma \mathrm{Y} 2 & =\text { skor total kuadrat lalu dijumlahkan } \\
\mathrm{n} & =\text { jumlah responden }
\end{array}
$$

setelah mendapatkan $\mathrm{r}_{\text {hitung, }}$, selanjutnya dihitung dengan Uji$\mathrm{t}$ dengan persamaan $\mathbf{5}$ :

$$
\text { thitung }=\frac{r \cdot \sqrt{n-2}}{\sqrt{1-r^{2}}}
$$

dimana:

$$
\begin{array}{ll}
\mathrm{t}_{\text {hitung }} & =\text { nilai } \mathrm{t} \text { yang dihitung } \\
\mathrm{r} & =\text { Koefisien korelasi } \mathrm{r}_{\text {hitung }} \\
\mathrm{n} & =\text { Jumlah responden }
\end{array}
$$

Instrumen penelitian dapat dikatakan valid jika memenuhi persyaratan sebagai berikut:

Hasil valid $\quad=$ Jika nilai $t_{\text {hitung }}>t_{\text {tabel }}$

Hasil tidak valid $=$ Jika nilai $t_{\text {hitung }}<\mathrm{t}_{\text {tabel }}$

\section{Uji Reliabilitas}

Konsep reliabilitas adalah sejauh mana hasil suatu penelitian dapat dipercaya. Hasil pengukuran dapat dipercaya hanya apabila dalam beberapa kali pelaksanaan pengukuran terhadap suatu kelompok subjek selalu diperoleh hasil yang relatif sama [23].

Hasil ukur erat kaitannya dengan error dalam pengambilan sampel (sampling error) yang mengacu pada inkonsistensi hasil ukur apabila pengukuran dilakukan ulang pada kelompok individu yang berbeda. Tujuan utama pengujian reliabilitas adalah untuk mengetahui konsistensi atau keteraturan hasil pengukuran apabila instrumen tersebut digunakan lagi sebagai alat ukur suatu responden. Hasil uji reliabilitas mencerminkan dapat dipercaya atau tidaknya suatu instrumen penelitian berdasarkan tingkat kemantapan dan ketepatan suatu alat ukur dalam pengertian bahwa hasil pengukuran yang didapatkan merupakan ukuran yang benar dari suatu ukuran. Untuk mencapai hal tersebut, dilakukan uji reliabilitas dengan menggunakan metode diukur berdasarkan skala Alpha Cronbac's 0 sampai 1 [23]. Merupakan uji konsistensi dari instrumen bila diukur secara berulang-ulang. Uji reliabilitas dapat menggunakan persamaan $\mathbf{6}$ :

$r 11=\frac{2 \cdot r_{b}}{1+r_{b}}$

dimana:

$\mathrm{r}_{11}=$ koefisien reliabilitas internal seluruh item

$\mathrm{rb}=$ koefisien product moment (dari $\mathrm{r}_{\text {hitung }}$ )

Instrumen kuesioner dapat dikatakan reliabel jika:

hasil reliabel $=$ Jika nilai $\mathrm{r}_{11}>\mathrm{r}_{\text {tabel }}$

hasil tidak reliabel $=$ Jika nilai $\mathrm{r}_{11}<\mathrm{r}_{\text {tabel }}$

\section{Uji Hipotesis}

Korelasi sederhana digunakan untuk mencari besarnya hubungan antara satu variabel bebas (X) terhadap variabel terikat (Y). Terdapat 6 (enam) langkah dalam melakukan uji hipotesis penelitian. Berikut ini merupakan pembahasan mengenai langkah dalam uji hipotesis [23]:

a. Langkah 1. Membuat $\mathrm{H}_{1}$ dan $\mathrm{H}_{0}$ dalam bentuk kalimat.

$\mathrm{H}_{1}=$ terdapat hubungan yang signifikan antara metode $\mathrm{A}$ terhadap objek B.

$\mathrm{H}_{0}=$ tidak terdapat hubungan yang signifikan antara metode A terhadap objek B.

b. Langkah 2. Membuat H1 dan H0 dalam bentuk statistic.

$$
\begin{aligned}
& \mathrm{H} 1: \mathrm{r} \neq 0 \\
& \mathrm{H} 0: \mathrm{r}=0
\end{aligned}
$$

c. Langkah 3. Membuat tabel penolong untuk menghitung korelasi sederhana. Data awal yang diperlukan pada penelitian ini adalah data penelitian untuk variabel $\mathrm{X}$ dan Y.

Pada tahap ini dilakukan perhitungan korelasi antar variabel $\mathrm{X}$ dan $\mathrm{Y}$ meliputi:

- Mencari nilai korelasi X terhadap Y

- $\mathrm{X}=$ Variabel $1=$ Penerapan BIM 4D dan M-PERT

- $\mathrm{Y}=$ Variabel 2 = Pekerjaan struktur hunian bertingkat tinggi

Hasil statistik dianalisis dan dievaluasi terkait faktor-faktor paling berpengaruh dalam penerapan BIM 4D dan M-PERT pada struktur hunian bertingkat tinggi yang terdiri dari:

- Sub factor paling berpengaruh.

- Main factor paling berpengaruh.

- Variabel paling berpengaruh.

- Keputusan hipotesis diterima atau ditolak.

\section{Hasil dan Pembahasan}


Penyusunan kuesioner dilakukan setelah dilakukan studi literatur. Komponen kuesioner seperti variabel, main factor dan sub factor sudah diperoleh. Tahap selanjutnya yaitu menghimpun hasil studi literatur menjadi satu bentuk daftar pertanyaan yang akan diajukan kepada responden. Detail mengenai sub factor penelitian ini disajikan dalam bentuk tabel yang dapat dilihat pada Tabel 3. Pada awal bagian ini, perlu diberikan suatu pengantar yang memuat hal-hal yang dilakukan beserta analisis yang digunakan dalam menyelesaikan penelitian. Selanjutnya secara terperinci dan tahap demi tahap tujuan penelitian dibahas dan dianalisis secara detail dan tajam, dengan metodologi penelitian sampai diperoleh suatu hasil penelitian. Analisis dan pembahasan ini dilakukan untuk semua tujuan yang telah ditetapkan pada tujuan penelitian.

Mempertimbangkan bahwa untuk penerapan BIM di Indonesia adalah platform baru di dunia konstruksi di Indonesia maka penentuan responden siapa yang dapat memberikan jawaban yang sesuai menjadi sangat penting. Sehingga untuk memastikan jawaban responden dapat memenuhi syarat, maka penulis menetapkan target responden yang memiliki kemampuan untuk menjawab kuesioner dengan baik.

Pengumpulan data kuesioner dilakukan terlebih dahulu menyebarkan kuesioner kepada target responden yang ahli di bidang estimasi dan penghitungan volume pekerjaan proyek bangunan gedung bertingkat tinggi. Dilanjutkan disebarkan kepada lini manajer konstruksi yang memahami proses pembuatan Rencana Anggaran Biaya dan proses persiapan pekerjaan konstruksi. Survei yang dilakukan selama 14 hari dengan menyebarkan 50 paket kuesioner. Paket kuesioner yang berhasil diisi sebanyak 38 dan yang tidak kembali sebanyak 12. Untuk lebih jelasnya dapat dilihat pada Tabel 4 dan Gambar 5.

Target berikutnya adalah pengalaman responden, ada 3 kriteria responden dalam penelitian ini, kurang dari 5 tahun, 5 - 10 tahun, dan lebih dari 10 tahun. Hasil dari kuisoner dapat dilihat pada Tabel 5 dan Gambar 7.

Tabel 5. Target responden

\begin{tabular}{clll}
\hline No. & \multicolumn{1}{c}{ Posisi } & \multicolumn{1}{c}{ Jumlah } & Prosentase (\%) \\
\hline 1 & Estimator & 5 & $34,21 \%$ \\
2 & Manager Teknik & 7 & $13,15 \%$ \\
3 & Site Manager & 16 & $31,55 \%$ \\
4 & Project Manager & 8 & $15,78 \%$ \\
5 & Lain lain & 2 & $5,26 \%$ \\
& Total & 38 & $100 \%$ \\
\hline
\end{tabular}

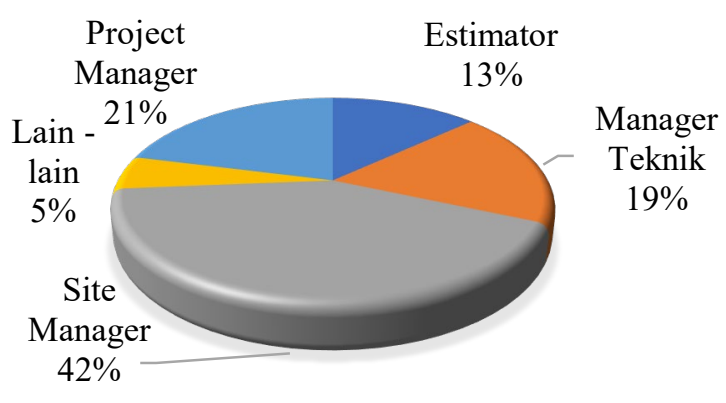

Gambar 6. Responden

Tabel 6. Pengalaman responden

\begin{tabular}{cccc}
\hline No. & Pengalaman & Jumlah & Prosentase \\
\hline 1 & $<5$ Tahun & 8 & $21,05 \%$ \\
2 & 5- 10 Tahun & 14 & $36,84 \%$ \\
3 & $>10$ Tahun & 16 & $42,10 \%$ \\
& Total & 38 & $100 \%$ \\
\hline
\end{tabular}

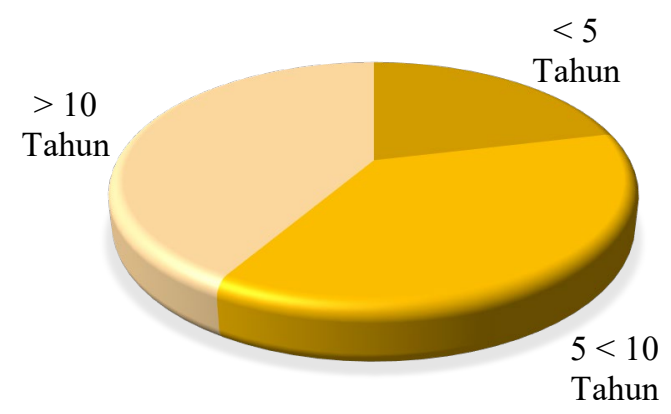

Gambar 7. Pengalaman responden

Tabel 6 dan Gambar 9 menunjukkan bahwa persentase pengalaman responden dalam penelitian ini yaitu $5<10$ tahun sebanyak 39,47\%. Disusul dengan persentase pengalaman $>10$ tahun sebesar $42,10 \%$ dan persentase pengalaman responden terendah dalam penelitian ini yaitu $<5$ tahun sebesar $21,05 \%$. Sedangkan untuk tipe pelaksanaan proyek yang sedang atau telah dikerjakan dapat dilihat pada Tabel 6 dan Gambar 8.

Tabel 7 dan Gambar 10 menunjukkan bahwa persentase tertinggi pelaksanaan untuk tipikal bangunan dalam penelitian ini yaitu bangunan apartemen sebesar 73,68\%. Persentase tertinggi berikutnya untuk pelaksanaan proyek bangunan kantor sebesar $21,05 \%$. Persentase terendah pelaksanaan proyek diperoleh pada tipikal bangunan hotel yaitu sebesar 5,26\%. 
Tabel 3. Main Factor dan sub factor

\begin{tabular}{|c|c|c|c|}
\hline Variabel & Main Factor & No & Sub factor \\
\hline \multirow[t]{6}{*}{ M-PERT } & penjadwalan & $\mathrm{X} 1$ & Menggabungkan kegiatan proyek ke dalam satu group [24] \\
\hline & & $\mathrm{X} 2$ & Perhitungan dapat dikembangkan secara manual [24] \\
\hline & & $\mathrm{X} 3$ & $\begin{array}{l}\text { kemiripan yang lebih tinggi antara jaringan terjadwal dan proyek } \\
\text { konstruksi nyata [24] }\end{array}$ \\
\hline & & $\mathrm{X} 4$ & Korelasi antara aktifitas bisa berbeda [24] \\
\hline & & $\mathrm{X} 5$ & Formula lebih sederhana [25] \\
\hline & & $\mathrm{X} 6$ & Pemodelan aktifitas [25] \\
\hline \multirow[t]{13}{*}{ BIM 4D } & Perencanaan & $\mathrm{X} 7$ & perencanaan keselamatan [26] \\
\hline & & $\mathrm{X} 8$ & mengintegrasikan penjadwalan dan perencanaan [27] \\
\hline & pemodelan & X9 & Rencana tata letak situasi (Site Layout) [26] \\
\hline & 4D & $\mathrm{X} 10$ & Perencanaan pengadaaan material [26] \\
\hline & & $\mathrm{X} 11$ & Perencanaan desain bangunan [26] \\
\hline & & $\mathrm{X} 12$ & Perencanaan metode kerja yang di gunakan [26] \\
\hline & Simulasi dan & $\mathrm{X} 13$ & Memfasilitasi pemahaman tentang proses konstruksi [26] \\
\hline & Visualisasi & $\mathrm{X} 14$ & Mengkomunikasikan ruang kerja [26] \\
\hline & & $\mathrm{X} 15$ & Visualisasi tahapan konstruksi [26] \\
\hline & & $\mathrm{X} 16$ & laporan progres pekerjaan [26] \\
\hline & & $\mathrm{X} 17$ & Meningkatkan produktivitas dan efisiensi pekerjaan [27] \\
\hline & & $\mathrm{X} 18$ & Mengurangi terjadinya kesalahan desain [27] \\
\hline & & X19 & validasi jadwal kegiatan [26] \\
\hline Pekerjaan & Lingkup & $\mathrm{X} 20$ & Detail gambar dan spesifikasi desain [28] \\
\hline Struktur & pekerjaan & $\mathrm{X} 21$ & Kompleksitas proyek [28] \\
\hline Hunian & & $\mathrm{X} 22$ & Jenis pekerjaan [28] \\
\hline Bertingkat & & $\mathrm{X} 23$ & Area pekerjaan $[28]$ \\
\hline \multirow[t]{18}{*}{ Tinggi } & & $\mathrm{X} 24$ & Ukuran dan nilai proyek [28] \\
\hline & Faktor & $\mathrm{X} 25$ & Waktu yang direncanakan untuk pekerjaan konstruksi [29] \\
\hline & waktu & $\mathrm{X} 26$ & Waktu yang dibutuhkan untuk mengerjakan VO [29] \\
\hline & & $\mathrm{X} 27$ & presentase keterlambatan [29] \\
\hline & & $\mathrm{X} 28$ & Rata-rata keterlambatan dalam persetujuan klaim [29] \\
\hline & & X29 & Rata-rata keterlambatan dalam pembayaran dari owner [29] \\
\hline & & $\mathrm{X} 30$ & waktu yang dibutuhkan untuk pekerjaan rework [29] \\
\hline & & $\mathrm{X} 31$ & Keterlambatan akibat kekurangan material [29] \\
\hline & Faktor biaya & $\mathrm{X} 32$ & Cash flow proyek [29] \\
\hline & & X33 & harga material dan peralatan [29] \\
\hline & & $\mathrm{X} 34$ & harga upah [29] \\
\hline & & $\mathrm{X} 35$ & Kurang nya informasi spek pada saat tender [30] \\
\hline & & X36 & eskalasi harga [29] \\
\hline & & $\mathrm{X} 37$ & Kesalahan dalam Dokumen Kontrak (Bill of Quantity) [30] \\
\hline & Faktor & $\mathrm{X} 38$ & Pekerja atau sub yang tidak terlatih [31] \\
\hline & Kualitas & X39 & Kurang nya pelaksana dilapangan [31] \\
\hline & & $\mathrm{X} 40$ & Kualitas material [31] \\
\hline & & $\mathrm{X} 41$ & Perubahan desain [31] \\
\hline
\end{tabular}

Tabel 7. Tipe proyek responden

\begin{tabular}{cccc}
\hline No. & Tipikal & Jumlah & Prosentase \\
\hline 1 & Perkantoran (office) & 8 & $21,05 \%$ \\
2 & Apartemen & 28 & $36,84 \%$ \\
3 & Hotel & 2 & $42,10 \%$ \\
& Total & 38 & $100 \%$ \\
\hline
\end{tabular}

Pengujian data dilakukan setelah pendataan, langkah selanjutnya adalah dengan melakukan uji reliabilitas, dengan signifikansi untuk $\alpha=0.05$ dan $\mathrm{dk}=38-2=36$, dengan uji dua arah/pihak maka diperoleh $r_{\text {tabel }}=0,3004$, berdasarkan $r_{\text {tabel }}$ pada Tabel 8.

Proses selanjutnya adalah melakukan menguji setiap reliabilitas setiap variabel pertanyaan (sub factor) dengan membandingkan $r_{11}$ dengan $r_{\text {tabel }}$. Nilai $r_{11}$ dihitung dengan menggunakan Spearman Brown (persamaan 6). Hasil analisis didapatkan bahwa semua sub factor reliabel. 


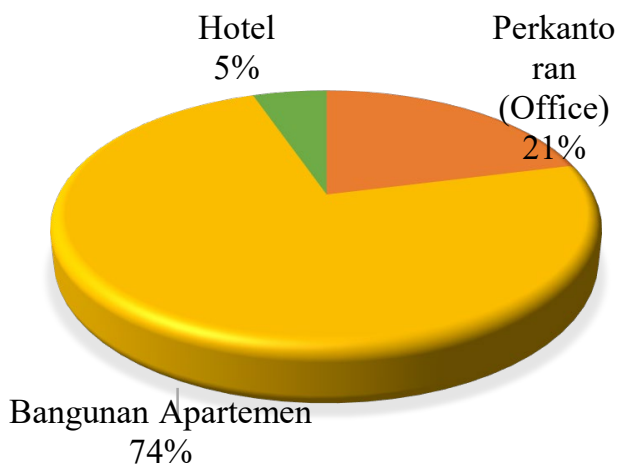

Gambar 8. Tipe proyek yang sedang dilaksanakan responden

Tabel 8. Tingkat signifikansi

\begin{tabular}{ccccccc}
\hline \multicolumn{7}{c}{ Tingkat signifikansi untuk uji satu arah } \\
Df = (N-2) & 0,05 & 0,025 & 0,01 & 0,005 & 0,0005 \\
\multicolumn{7}{c}{ Tingkat signifikansi ntuk uji dua arah } \\
& 0,1 & 0,05 & 0,02 & 0,01 & 0,001 \\
\hline 35 & 0,274 & 0,324 & 0,281 & 0,418 & 0,518 \\
\hline 36 & 0,270 & 0,320 & 0,376 & 0,412 & 0,512 \\
37 & 0,267 & 0,316 & 0,371 & 0,407 & 0,506 \\
39 & 0,263 & 0,312 & 0,371 & 0,407 & 0,506 \\
40 & 0,260 & 0,308 & 0,362 & 0,397 & 0,495 \\
41 & 0,257 & 0,304 & 0,357 & 0,393 & 0,489 \\
42 & 0,254 & 0,300 & 0,353 & 0,388 & 0,484 \\
& 0,251 & 0,297 & 0,349 & 0,384 & 0,479 \\
\hline
\end{tabular}

Setelah $\mathrm{r}_{11}$ setiap sub factor terdefinisikan dan hasil kuesioner sudah dinyatakan reliabel pada Uji Reliabilitas, maka proses selanjutnya adalah melakukan Uji Validitas. Uji tersebut akan menunjukkan seberapa handal atau sahih dari suatu alat ukur. Alat ukur yang kurang valid berarti memiliki validitas yang rendah. Uji Validitas ini dilakukan dengan Uji$\mathrm{T}$, dengan persamaan 5. Hasil analisis didapatkan bahwa semua sub factor valid.

Dikarenakan penelitiaan ini terdiri atas 2 variabel bebas, maka untuk menguji hipotesis penelitian ini digunakan uji korelasi ganda. Korelasi ganda digunakan untuk mencari besarnya hubungan antara dua variabel bebas (X) atau lebih secara simultan terhadap variabel terikat. Hasil analisis dapat dilihat pada Tabel 9.

Berdasarkan hasil perhitungan nilai korelasi pada Tabel 8 selanjutnya didapatkan nilai korelasi antar variabel dan korelasi ganda (rx1.x2.y) dengan Persamaan 7.

$r_{x 1 . x 2 . y}=\sqrt{\frac{\left(r_{x 1 . y}\right)^{2}+\left(r_{x 2 . y}\right)^{2}-2 \cdot\left(r_{x 1 . y}\right)\left(r_{x 2 . y}\right)\left(r_{x 1 . x 2}\right)}{1-\left(r_{x 1 . x 2}\right)^{2}}}$
Dari persamaan 7 didapatkan nilai korelasinya adalah 0,847 yang artinya korelasi sangat kuat. Uji Signifikansi dilakukan dengan Uji F, dengan kaidah pengujian sebagai berikut :

$\mathrm{F}_{\text {hitung }}>\mathrm{F}_{\text {tabel }}$ maka $\mathrm{H} 1$ diterima $\mathrm{H} 0$ ditolak

$F_{\text {hitung }}=\frac{\left(\frac{r^{2}}{k}\right)}{\frac{1-r^{2}}{n-k-1}}$

Dari persamaan 8 didapatkan nilai $\mathrm{F}$ hitung 44,46 dan $F_{\text {tabel }}$ 3,27. Berdasarkan hasil perhitungan $F_{\text {hitung dan }} F_{\text {tabel }}$ dan kaidah pengujian signifikansi, dapat ditarik kesimpulan bahwa $F_{\text {hitung }}$ (sebesar 44.46) > Ftabel (sebesar 3,27), maka $\mathrm{H}_{1}$ diterima - $\mathrm{H}_{0}$ ditolak artinya terdapat pengaruh yang signifikan antara BIM 4D \& M-PERT terhadap pekerjaan struktur hunian bertingkat tinggi.

Tabel 9. Ringkasan hasil korelasi

\begin{tabular}{cccc}
\hline No. & Simbol & Nilai & Prosentase \\
\hline 1 & $\mathrm{r}_{\mathrm{X} 1 . \mathrm{Y}}$ & 0,7143 & Kuat \\
2 & $\mathrm{r}_{\mathrm{X} 2 . \mathrm{Y}}$ & 0,8294 & Sangat kuat \\
3 & $\mathrm{r}_{\mathrm{X} 1 . \mathrm{X} 2}$ & 0,7164 & Kuat \\
\hline
\end{tabular}

Tabel 10. Sepuluh sub factor paling berpengaruh

\begin{tabular}{|c|c|c|}
\hline Rank & Sub factor & Nilai \\
\hline 1 & Detail gambar dan spesifikasi desain & 0,965 \\
\hline 2 & Schedule Proyek & 0,956 \\
\hline 3 & presentase keterlambatan & 0,952 \\
\hline 4 & Pemodelan aktifitas & 0,943 \\
\hline 5 & $\begin{array}{l}\text { Dapat menggabungkan kegiatan } \\
\text { proyek ke dalam satu }\end{array}$ & 0,934 \\
\hline 6 & $\begin{array}{l}\text { kemiripan yang lebih tinggi antara } \\
\text { jaringan terjadwal dan proyek } \\
\text { konstruksi nyata }\end{array}$ & 0,930 \\
\hline 7 & Perencanaan desain bangunan & 0,921 \\
\hline 8 & $\begin{array}{l}\text { mengintegrasikan penjadwalan dan } \\
\text { perencanaan }\end{array}$ & 0,912 \\
\hline 9 & Visualisasi tahapan konstruksi & 0,908 \\
\hline 10 & $\begin{array}{l}\text { Meningkatkan produktivitas dan } \\
\text { efisiensi pekerjaan }\end{array}$ & 0,899 \\
\hline
\end{tabular}

Langkah selanjutnya melakukan analisis faktor-faktor yang paling berpengaruh dalam objek penelitian dengan menggunakan metode Relative Importance Index (RII). Untuk menghitung Relative Importance Index dapat menggunakan persamaan (1). Hasil perhitungan RII dapat dilihat pada Tabel 10, Tabel 11, dan Tabel 12. 
Tabel 11. Main Factor yang paling berpengaruh

\begin{tabular}{cl}
\hline No. & \multicolumn{1}{c}{ Main factor } \\
\hline 1 & Lingkup Pekerjaan \\
2 & Faktor Kualitas \\
3 & Faktor Waktu \\
4 & Penjadwalan \\
5 & Faktor Biaya \\
6 & Perencanaan dan pemodelan 4D \\
7 & Simulasi dan Visualisasi \\
\hline
\end{tabular}

Tabel 12. Variabel yang paling berpengaruh

\begin{tabular}{cl}
\hline No. & \multicolumn{1}{c}{ Main factor } \\
\hline 1 & Pekerjaan Struktur Bangunan Hunian Bertingkat \\
& Tinggi \\
2 & M-PERT \\
3 & BIM 4D \\
\hline
\end{tabular}

\section{Simpulan}

Simpulan penelitian ini yaitu terdapat pengaruh yang signifikan antara BIM 4D \& M-PERT terhadap pekerjaan struktur hunian bertingkat tinggi. Dari hasil penelitian didapatkan 10 faktor yang berpengaruh terhadap kinerja waktu dengan menggunakan BIM 4D dan M-PERT pada pekerjaan struktur bangunan hunian, antara lain detail gambar, schedule proyek, presentase keterlambatan, pemodelan aktivitas, penggabungan kegiatan proyek, kemiripan jaringan, perencanaan desain bangunan, integrasi penjadwalan, visualisasi, dan meningkatkan produktivitas.

\section{Daftar Pustaka}

[1] R. Levin and Kirkpatrick. C.A, Perentjanaan dan Pengawasan Dengan PERT dan CPM. Jakarta: Bharatara, 1972.

[2] M. Gündüz, Y. Nielsen, and M. Özdemir, "Quantification of delay factors using the relative importance index method for construction projects in Turkey," J. Manag. Eng., 2013.

[3] H. R. Gobi, "Colliers Quarterly Jakarta Apartment and Expat Housing Q4 2019 Report,” no. January 2020, pp. 1-7, 2020.

[4] Sugiyono, Metode penelitian pendidikan: (pendekatan kuantitatif, kualitatif dan $R \& D$ ). Alfabeta, 2008.

[5] Y. S. Susilo, “Analisis Pelaksanaan Proyek Dengan Metode CPM Dan PERT (Studi Kasus Proyek Pelaksanaan Main Stadium University of Riau(Multiyears) ).," p. 16, 2011.

[6] I. Raharja, "Analisa Penjadwalan Proyek Dengan Metode Pert Di Pt. Hasana Damai Putra Yogyakarta Pada Proyek Perumahan Tirta Sani," Bentang, vol. 2, no. 1 , p. 262530,2014

[7] M. A. Alwi and I. Syahrizal, "Analisis Penerapan Sistem Penjadwalan CPM, PERT, Dan LOB Pada Penjadwalan Proyek ( Studi Kasus: Pembangunan Gedung Kantor PT . Jasa Asuransi Indonesia Pematang Siantar )," J. Tek. Sipil USU, pp. 1-13, 2015.

[8] S. Suherman, “Analisa Penjadwalan Proyek Menggunakan PDM dan Pert Serta Crash Project (Studi kasus: Pembangunan Gedung Main Power House PT. Adhi Karya)," J. Tek. Ind. J. Has. Penelit. dan Karya Ilm. dalam Bid. Tek. Ind., vol. 2, no. 1, p. 31, 2016.

[9] S. Qomariyah and F. Hamzah, "Analisis Network Planning Dengan Cpm (Critical Path Method) Dalam Rangka Efisiensi Waktu Dan Biaya Proyek," vol. 1, no. 4, pp. 408-416, 2013.

[10] M. Abdelghany, R. Rahwan, I. Abotaleb, A. Fathy, and A. Albughadadi, "Value Engineering Applications to Improve Value in Residential Projects," no. October 2016, pp. 0-10, 2015.

[11] J. R. Handoko and O. Gondokusumo, "Comparison of PERT and M-PERT scheduling for a construction project in Malang, Indonesia," IOP Conf. Ser. Mater. Sci. Eng., vol. 508, no. 1, 2019.

[12] A. E. Husin, F. Fahmi, S. Rahardjo, I. P. Siregar, and B. D. Kussumardianadewi, "M-PERT and lean construction integration on steel construction works of warehouse buildings," Int. J. Eng. Adv. Technol., vol. 8, no. 4, pp. 696-702, 2019.

[13] A. E. Husin and C. B. Sulistyaningtyas, "project by MPERT utilization Time performance improvement of hospital building structure construction project by MPERT utilization,” vol. 7, no. November 2018, 2019.

[14] H. A. Wasmi and D. Castro-Lacouture, "Potential Impacts of BIM-Based Cost Estimating in Conceptual Building Design: A University Building Renovation Case Study," Constr. Res. Congr. 2016 Old New Constr. Technol. Converg. Hist. San Juan - Proc. 2016 Constr. Res. Congr. CRC 2016, no. August, pp. 408 417, 2016.

[15] S. Scheer, R. Mendes, T. F. Campestrini, and M. C. Garrido, "On-site BIM model use to integrate 4D/5D activities and construction works: A case study on a brazilian low income housing enterprise," Comput. Civ. Build. Eng. - Proc. 2014 Int. Conf. Comput. Civ. Build. Eng., no. Ferreira 2007, pp. 455-462, 2014.

[16] J. Jupp, “4D BIM for Environmental Planning and Management," Procedia Eng., vol. 180, pp. 190-201, 
2017.

[17] S. M. Jununkar, P. D. S. Aswar, and P. D. L. Mittapalli, "Application of Bim and Construction Process Simulation Using 5D Bim for Residential Building Project," Int. Res. J. Eng. Technol., vol. 4, no. 7, pp. 1063-1067, 2017.

[18] S. Malsane, "Simulate Construction Schedules Using Bim 4D Application To Simulate Construction Schedules Using Bim 4D," no. January, 2017.

[19] F. Leite, B. Akinci, and J. Garrett, "IDENTIFICATION OF DATA ITEMS NEEDED FOR AUTOMATIC CLASH DETECTION IN MEP DESIGN COORDINATION,” pp. 886-895, 2009.

[20] Riduan, Skala pengukuran variabel-variabel penelitian. Bandung: Alfabeta, 2008.

[21] Sukardi, Metodologi penelitian pendidikan: kompetensi dan praktiknya / Sukardi. Jakarta: Bumi Aksara, 2005.

[22] A. Wael, R. S. N. Saadan, A. Wail, and S. Basel, "Delay Factors Impacting Construction Projects in Sana ' a -Yemen 1," PM World J., vol. VII, no. XII, pp. 1-28, 2018.

[23] A. Saifuddin, Reliabilitas dan Validitas. Yogyakarta: Pustaka Belajar, 2006.

[24] P. Ballesteros-Pérez, "M-PERT: Manual ProjectDuration Estimation Technique for Teaching Scheduling Basics," J. Constr. Eng. Manag., 2017.

[25] A. E. Husin and R. F. Ashadi, "Metode Penjadwalan M-PERT Sebagai Alternatif Solusi Akurasi Estimasi Jurnal Aplikasi Teknik Sipil Metode Penjadwalan M-
PERT Sebagai Alternatif Solusi Akurasi Estimasi Waktu Proyek ( Review )," no. February, 2019.

[26] B. J. Gledson and D. Greenwood, "The adoption of 4D BIM in the UK construction industry: An innovation diffusion approach," Eng. Constr. Archit. Manag., vol. 24, no. 6, pp. 950-967, 2017.

[27] Y. Y. Al-Ashmori et al., "BIM benefits and its influence on the BIM implementation in Malaysia," Ain Shams Eng. J., vol. 11, no. 4, pp. 1013-1019, 2020 .

[28] W. Soon Han, A. Md Yusof, S. Ismail, and N. Choon Aun, "Reviewing the Notions of Construction Project Success," Int. J. Bus. Manag., vol. 7, no. 1, 2011.

[29] P. P. Bhangale, "Analysis of critical success factors for high rise buildings," Int. J. Latest Trends Eng. Technol., vol. 7, no. 2, pp. 159-165, 2016.

[30] J. K. Larsen, G. Q. Shen, S. M. Lindhard, and T. D. Brunoe, "Factors Affecting Schedule Delay, Cost Overrun, and Quality Level in Public Construction Projects," J. Manag. Eng., vol. 32, no. 1, p. 04015032 , 2016.

[31] O. A. Oyedele, "Factors Affecting Quality of Construction Projects in Swazilland," no. 2005, 2017. 